\title{
20. Characteristics of Air Pollution Concentration in Jakarta and Its Relationship with Local Flow Field \\ ジャワ島西部の局地風がジャカルタの大気污染に与え得る影響
}

\author{
アセップ ソフィアン*。北田敏廣*。倉田 学児 * \\ Asep SOFYAN*, Toshihiro KITADA*, Gakuji KURATA*
}

\begin{abstract}
The obtained spatial distributions of $\mathrm{NO}_{2}$ and $\mathrm{SO}_{2}$ show that the highest concentration appears near the high traffic main highway, and then higher concentrations in business center and industrial areas. The highest "oneday" $\mathrm{NO}_{2}$, appeared at a site near toll highway in central Jakarta, was $446.1 \mu \mathrm{g} / \mathrm{m}^{3} ; 16$ observation points including this site exceeded $92.5 \mu \mathrm{g} / \mathrm{m}^{3}$, the Jakarta ambient air quality standard (Jakarta AAQS). On the other hand, "one day" SO2 concentrations were below the Jakarta AAQS $260 \mu \mathrm{g} / \mathrm{m}^{3}$, though these at two sites were over the WHO AAQS 125 $\mu \mathrm{g} / \mathrm{m}^{3}$. Vertical profile, up to $110 \mathrm{~m}$ high, of air pollution was also studied using a high building in business center of Jakarta. The "one day" NO2 concentration were $119.8,101.3,87.6$, and $100.4 \mu \mathrm{g} / \mathrm{m}^{3}$ at $10,30,55$, and $110 \mathrm{~m}$ high, respectively, and similarly those for $\mathrm{SO} 2$ were $7.3,1.8,6.5$, and $16.2 \mu \mathrm{g} / \mathrm{m}^{3}$. It is interesting that the $\mathrm{SO} 2$ increases with height, suggesting huge point sources of power plants located along the coast in the north-eastern part of Jakarta may be resulted in this profile under the sea breeze condition. At the symposium, the results will be discussed together with CTM calculation.
\end{abstract}

KEYWORDS: Jakarta, air pollution, local flow, sea breeze

\section{Introduction}

Jakarta, Indonesia has experienced serious air pollution problems associated with the use of energy in the transport, domestic, and industrial sectors. Transportation sector is responsible for approximately $70 \%$ of the total emissions in Jakarta. Large scale stationary sources such as power plant and metal industries also degrade air quality in Jakarta.

For planning of long term better air quality, to know quantitative relationship between air quality and emission sources' distribution in the area is the first but the most important step, since air flow and other meteorological factors which are characteristic in the area largely affect the relationship in complex manner. As a "first" step to this purpose, we conducted field observation for air quality over Jakarta city using a number of passive samplers for $\mathrm{NO}_{2}$ and $\mathrm{SO}_{2}$ in August 2004. The samplers were distributed in 50 locations to measure both 1 day and 1 week averaged concentration distribution. Using the observed values, contours of $\mathrm{NO}_{2}$ and $\mathrm{SO}_{2}$ were plotted together with the model simulated surface wind fields.

To understand the characteristics and the development mechanism of complex local flows, numerical simulation over western Java area was performed using the Fifth-Generation Pennsylvania State University-National Center for Atmospheric Research Mesoscale Model Version 3.6 (hereafter will be abbreviated as MM5; see Dudhia et al., 2003 for the detail of the software). The simulations were done for 8-13 February 2001 in "rainy" season and for 6-19 August 2004 in "dry" season. Latitude and longitude at the southwest and northeast corners of the outermost domain were $8^{\circ} \mathrm{S}$ and $105^{\circ} \mathrm{E}$, and $5^{\circ} \mathrm{S}$ and $109^{\circ} \mathrm{E}$, respectively. The domain system used in this calculation is a triply nested two-way interacting mesh. The domain 1 has 50 X 37 horizontal grids points, the domain 2 has $73 \mathrm{X}$ 73 grids point, and the domain 3 has $82 \times 82$ grids points. The horizontal grid size was constant at 9,3 , and $1 \mathrm{~km}$ for the domain 1,2, and 3, respectively (see Fig 1). Each domain has 23 vertical grid points for the depth from the earth's surface to $100 \mathrm{hPa}$. The framework of meteorology in larger scale was provided by ECMWF data with a resolution of $0.5^{0} \times 0.5^{0}$.

*Department of Ecological Engineering, Toyohashi University of Technology, Toyohashi, Japan 


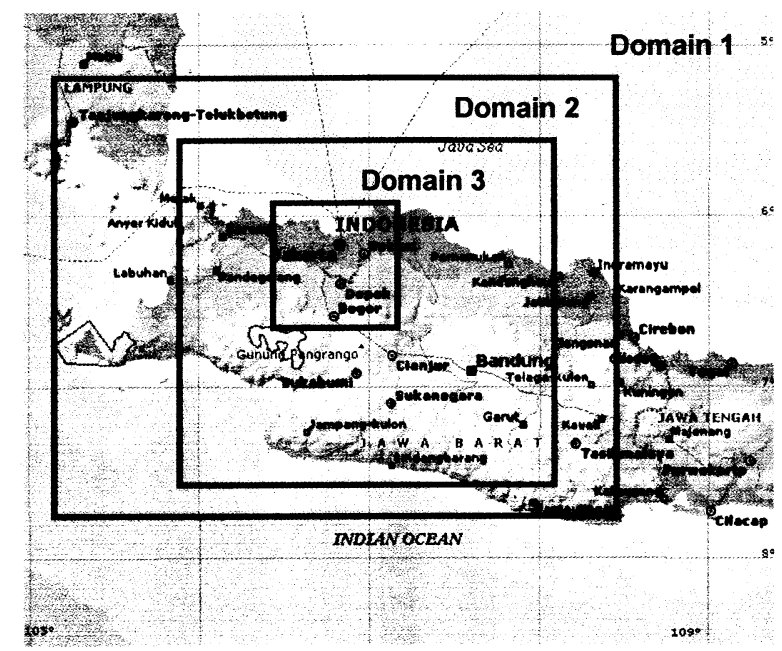

Fig. 1 The domain 1, 2, and 3 have $9 \mathrm{~km}, 3 \mathrm{~km}$, and $1 \mathrm{~km}$ grid size, respectively.

\section{NO2 and SO2 distribution over Jakarta}

For planning of long term better air quality, to know quantitative relationship between air quality and emission sources' distributions in the area is the first but the most important step, since air flow and other meteorological factors which are characteristic in the area largely affect the relationship in complex manner. As a "first" step to this purpose, we conducted field observation for air quality over Jakarta city using a number of passive samplers for $\mathrm{NO}_{2}$ and $\mathrm{SO}_{2}$ in August 2004. The samplers were distributed in 50 locations to measure both 1 day and 1 week averaged concentration distributions. Using the observed values, contours of $\mathrm{NO}_{2}$ and $\mathrm{SO}_{2}$ were plotted together with the model simulated surface wind fields (see Figs. 2 and 3). The obtained spatial distributions of $\mathrm{NO}_{2}$ and $\mathrm{SO}_{2}$ show that the highest concentration appears near the high traffic main highway, and then higher concentrations in business center and industrial areas. The highest "one-day" $\mathrm{NO}_{2}$ was $446.1 \mu \mathrm{g} / \mathrm{m}^{3}$, appeared at a site near toll highway in central Jakarta; 16 observation points including this site exceeded $92.5 \mu \mathrm{g} / \mathrm{m}^{3}$, which is the Jakarta ambient air quality standard (Jakarta AAQS). On the other hand, "one-day" $\mathrm{SO}_{2}$ concentrations were below the Jakarta AAQS $260 \mu \mathrm{g} / \mathrm{m}^{3}$, though these at two sites exceeded the WHO AAQS $125 \mu \mathrm{g} / \mathrm{m}^{3}$. Vertical profile, up to $110 \mathrm{~m}$ high, of air pollution was also studied using a high building in business center of Jakarta. The "one-day" $\mathrm{NO}_{2}$ concentrations were $119.8,101.3,87.6$, and $100.4 \mu \mathrm{g} / \mathrm{m}^{3}$ at $10,30,55$, and $110 \mathrm{~m}$ high, respectively, and similarly those for $\mathrm{SO}_{2}$ were $7.3,1.8,6.5$, and $16.2 \mu \mathrm{g} / \mathrm{m}^{3}$. It is interesting that the $\mathrm{SO}_{2}$ increases with height, suggesting huge point sources of power plants located along the coast in the north-eastern part of Jakarta may have resulted in this profile under the sea breeze condition (see Fig. 4).

\section{Local Flow Field over Jakarta area}

Characteristics of local flow in Jakarta area were numerically investigated for wet (rainy) and dry seasons. In the "rainy" season of 6-13 Feb, 2001, strong synoptic scale WSW wind regularly existed, and it suppressed penetration of NW sea breeze from the Java Sea on sunny days by forming a convergence with the sea breeze. Subsidence behind the convergence line (the sea breeze front) generated stable thin-layer above the sea breeze and thus part of the Jakarta area, indicating possible trap of the air pollutants below the layer and increase of air pollution potential. In the "dry" season of 6-19 Aug, 2004, though synoptic scale wind in upper layer was constantly southeasterly, it was very weak in the plain area of Jakarta because the synoptic SE wind was blocked by the mountains along the south coast of the Java Island. Hence, local winds of sea breeze from the Java Sea and valley wind over the northern slope of the southern mountains fully developed, forming one large scale combined local flow from the Java Sea to the mountains. This situation might give better ventilation of polluted air mass over Jakarta, though the "better ventilation" means export of air pollutants into the rural area. 


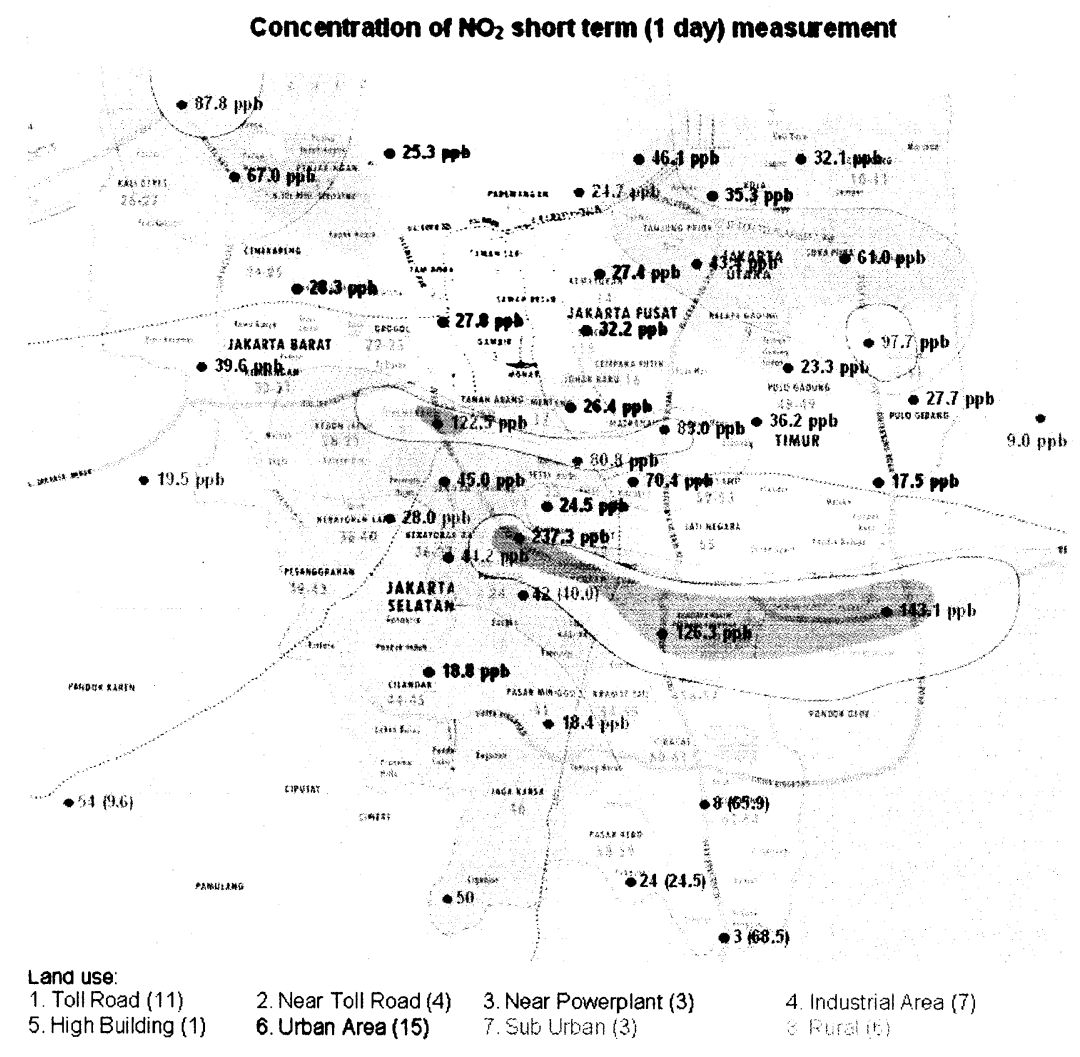

Concentration of $\mathrm{NO}_{2}$ long term (1 week) measurement

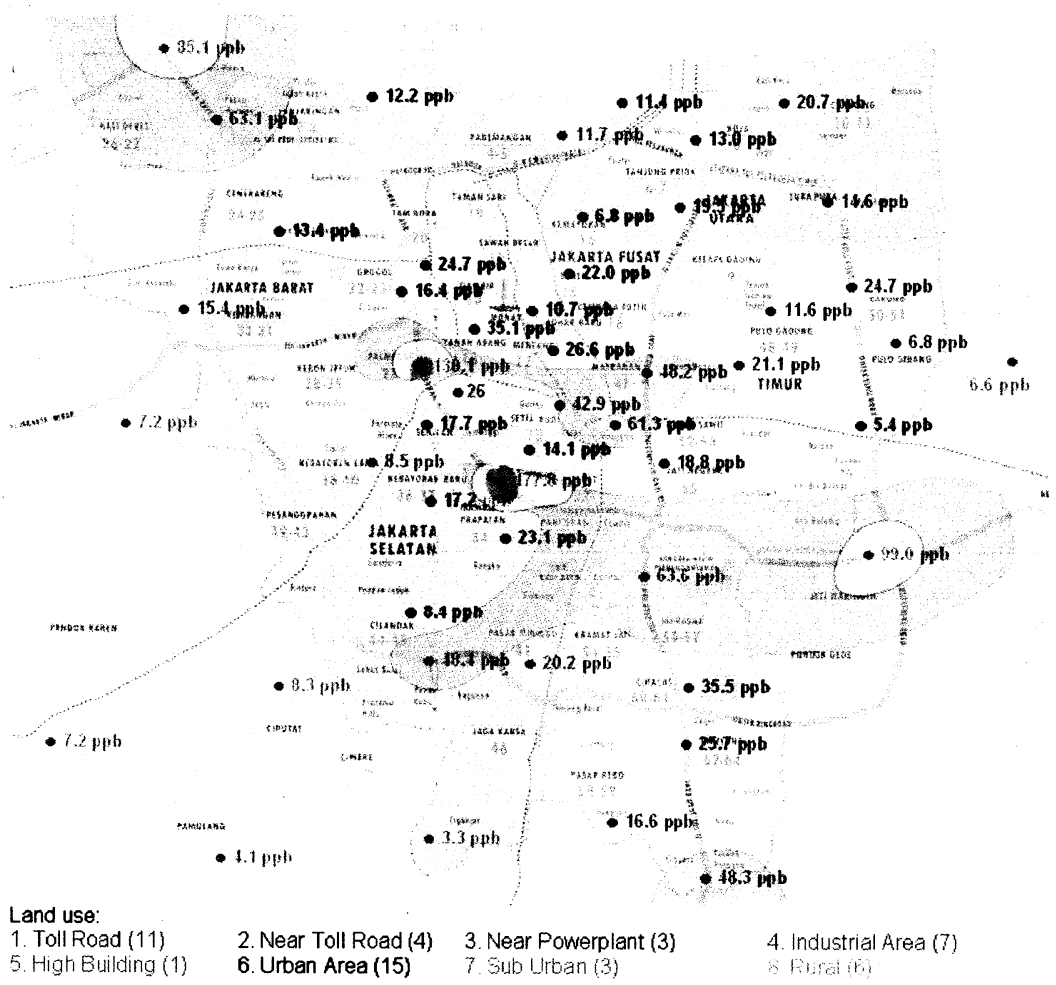

Fig. 2 Observed spatial distribution of NO2; measured with 50 passive samplers distributed over the greater Jakarta during short and long term measurements in August 2004. 


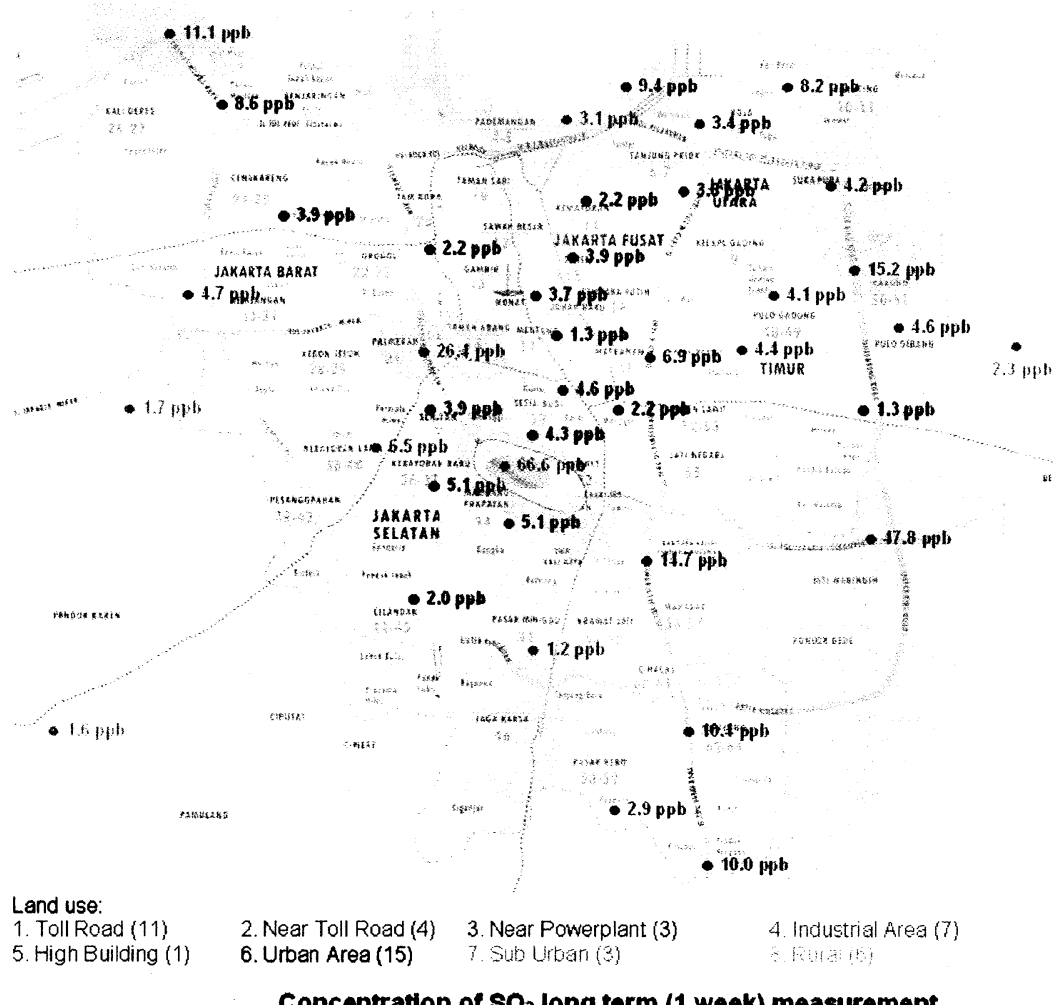

Concentration of $\mathrm{SO}_{2}$ long term (1 week) measurement

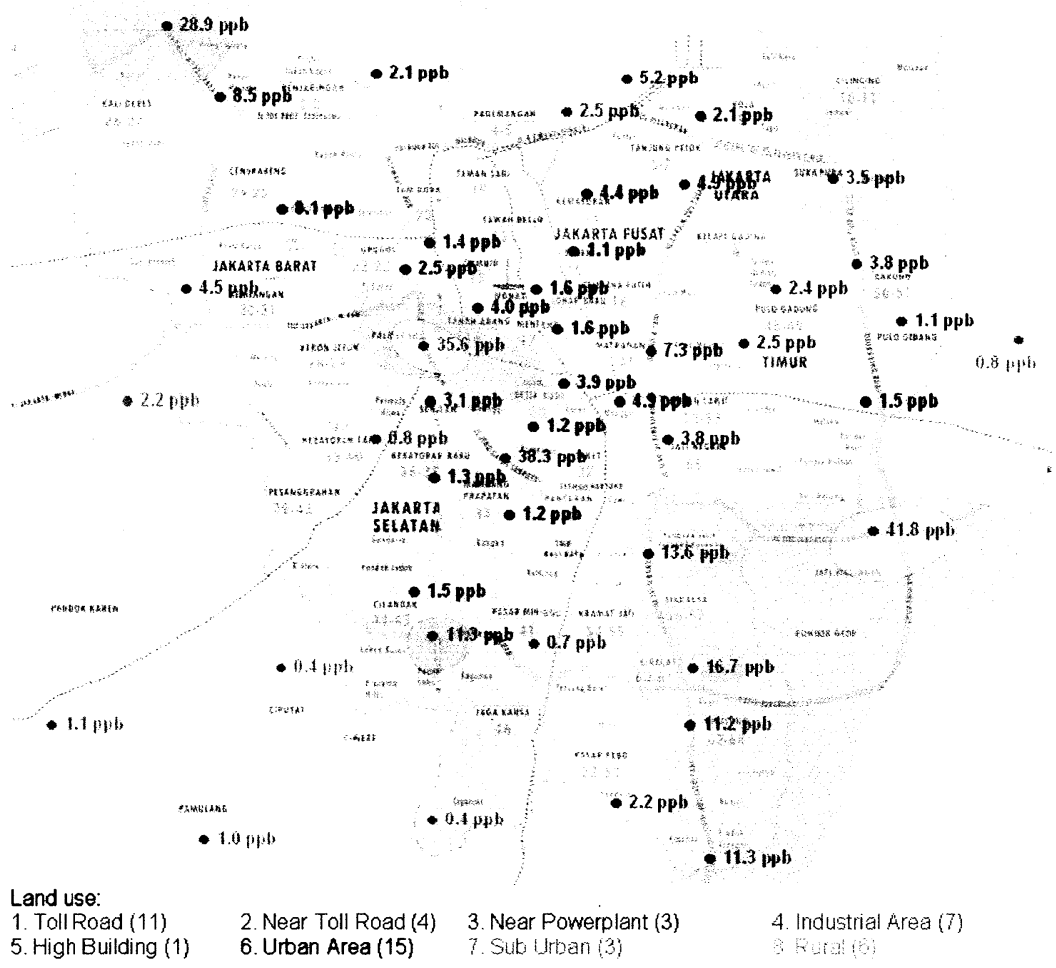

Fig. 3. Same as in Fig. 2 but for SO2. 

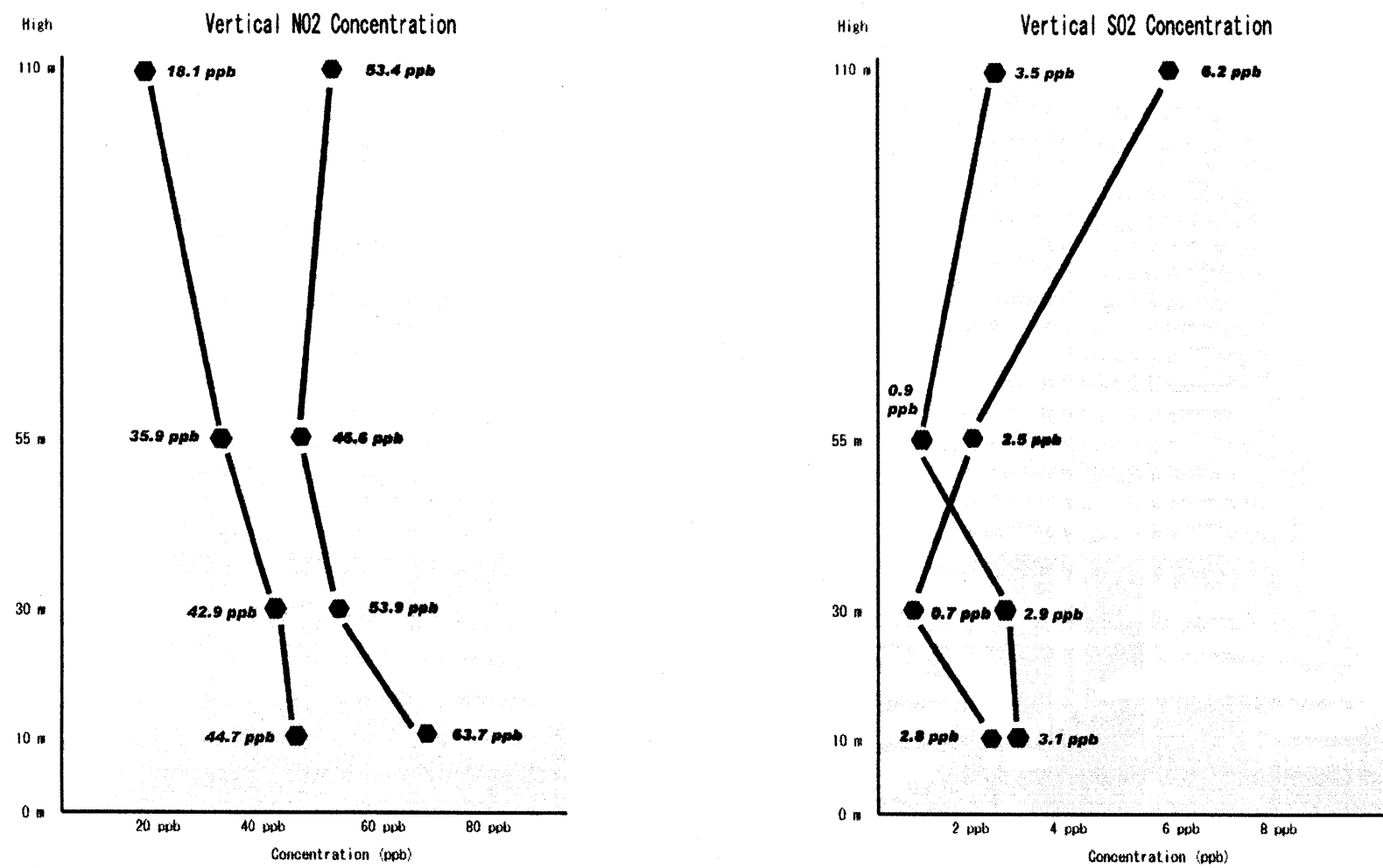

Fig. 4. Vertical profiles of measured NO2 and SO2 at business center of Jakarta: "black" for short term (1-day) and "red" for long term (1-week) term measurements.

\section{Conclusion}

Field observation for air quality over Jakarta city using a number of passive samplers for $\mathrm{NO}_{2}$ and $\mathrm{SO}_{2}$ in August 2004. The samplers were distributed in 50 locations to measure both 1 day and 1 week averaged concentration distributions. The obtained spatial distributions of $\mathrm{NO}_{2}$ and $\mathrm{SO}_{2}$ show that the highest concentration appears near the high traffic main highway, and then higher concentrations in business center and industrial areas.

Characteristics of local flow in Jakarta area were numerically investigated for wet (rainy) and dry seasons. In the "rainy" season of 6-13 Feb, 2001, strong synoptic scale WSW wind regularly existed, and it suppressed penetration of NW sea breeze from the Java Sea on sunny days by forming a convergence with the sea breeze. In the "dry" season of 6-19 Aug, 2004, though synoptic scale wind in upper layer was constantly southeasterly, it was very weak in the plain area of Jakarta because the synoptic SE wind was blocked by the mountains along the south coast of the Java Island. Hence, local winds of sea breeze from the Java Sea and valley wind over the northern slope of the southern mountains fully developed, forming one large scale combined local flow from the Java Sea to the mountains. This situation might give better ventilation of polluted air mass over Jakarta, though the "better ventilation" means export of air pollutants into the rural area.

\section{References}

\section{References}

1. Dudhia J and Gill D (2003), PSU/NCAR Mesoscale Modeling System Tutorial Class Notes and User's Guide: MM5 Modeling System Version 3, Mesoscale and Microscale Meteorology Division, National Center for Atmospheric Research.

2. Kitada T., Okamura K, and Tanaka S (1998) Effect of Topography and Urbanization on Local Winds and Thermal Environment in the Nohbi Plain, Coastal Region of Central Japan: A Numerical Analysis by Mesoscale Meteorological Model, Journal of Applied Meteorology, 37, 1026-1046.

3. McGregor, G. R. and Nieuwolt, S. (1998), Tropical Climatology, Second Edition, John Wiley \& Sons Ltd, 339pp.

4. Regmi, R.P., Kitada, T., and Kurata G.(2003) Numerical Simulation of Late Wintertime Local Flows in Kathmandu Valley, Nepal: Implication for Air Pollution Transport, Journal of Applied Meteorology, 42, 389402.

5. Riehl, H. (1979) Climate and Weather in the Tropics, Academic Press, 611p. 